\title{
Actinomadura rupiterrae sp. nov., isolated from cliff soil
}

\author{
Soon Dong Lee
}

Correspondence

Soon Dong Lee

sdlee@jejunu.ac.kr
Department of Science Education, Jeju National University, Jeju 690-756, Republic of Korea
The genus Actinomadura (Lechevalier \& Lechevalier, 1970b) belongs to the family Thermomonosporaceae Stackebrandt et al. 1997 emend. Zhang et al. 2001, together with the genera Actinoallomurus, Actinocorallia, Spirillospora and Thermomonospora, and at the time of writing consisted of 46 recognized species, including the recently described species Actinomadura miaoliensis (Tseng et al., 2009), A. keratinilytica (Puhl et al., 2009), A. flavalba (Qin et al., 2009), A. sputi (Yassin et al., 2010), A. scrupuli (Lee \& Lee, 2010), A. apis, A. rifamycini (Promnuan et al., 2011) and A. meridiana (Lee, 2012). Members of the genus contain meso-diaminopimelic acid as the diagnostic diamino acid and madurose as the characteristic sugar in the cell wall, with a murein structure of the acetyl type, and possess predominant menaquinones MK- $9\left(\mathrm{H}_{4}\right), \mathrm{MK}-9\left(\mathrm{H}_{6}\right)$ and MK-9 $\left(\mathrm{H}_{8}\right)$, phospholipid type PI (diphosphatidylglycerol and phosphatidylinositol present as major phospholipids), fatty acid type 3a [branched saturated and unsaturated fatty acids and tuberculostearic acid (TBSA)] and DNA G + C contents of $65-73$ mol\% (Kroppenstedt \& Goodfellow, 1991; Meyer, 1989). Morphologically, the genus is characterized by the production of well-developed, non-fragmenting vegetative hyphae and aerial mycelium,

The GenBank/EMBL/DDBJ accession number for the $16 \mathrm{~S}$ rRNA gene sequence of strain CS5-AC15 ${ }^{\top}$ is FM210337.

A supplementary table is available with the online version of this paper. on the tips of which spore chains of various lengths are arranged in straight, hooked or spiral form. The smooth, spiny or warty-surfaced spores are non-motile, oval or rodshaped. This genus can be readily differentiated from the other genera of the family Thermomonosporaceae on the basis of a combination of morphological and chemotaxonomic characteristics (Kroppenstedt \& Goodfellow, 2006). In this paper, the classification and identification of an Actinomadura strain that was isolated from soil is described by a polyphasic taxonomic approach.

Strain CS5-AC15 ${ }^{\mathrm{T}}$ was isolated from a soil sample taken from a cliff on Mara Island, Jeju, Republic of Korea. Bacterial isolation was performed by using the procedure described by Lee \& Jeong (2006) and starch-casein agar (Küster \& Williams, 1964) as the isolation medium. The pure culture was maintained on International Streptomyces Project (ISP) medium 2 (Shirling \& Gottlieb, 1966) and as mycelial fragments or spores in $20 \%(\mathrm{v} / \mathrm{v})$ glycerol at $-80{ }^{\circ} \mathrm{C}$. For phenotypic analysis and DNA-DNA hybridization, A. oligospora JCM $10648^{\mathrm{T}}$ was grown on ISP medium 2 at $30{ }^{\circ} \mathrm{C}$.

Growth and pigmentation of strain $\mathrm{CS} 5-\mathrm{AC}^{2} 5^{\mathrm{T}}$ were investigated on various media: yeast extract-malt extract agar (ISP 2), oatmeal agar (ISP 3), inorganic salts-starch agar (ISP 4), glycerol-asparagine agar (ISP 5), peptoneyeast extract-iron agar (ISP 6) and tyrosine agar (ISP 7) 
(Shirling \& Gottlieb, 1966). Results for cultural and morphological characterization were recorded after 2 weeks of incubation at $30{ }^{\circ} \mathrm{C}$. Spore chain morphology and spore ornamentation were observed by using scanning electron microscopy (JSM-6500; JEOL). The specimen for electron microscopy was fixed, dehydrated, critical-point-dried and coated with gold as described by Lee \& Jeong (2006) before observation.

Strain CS5-AC15 ${ }^{\mathrm{T}}$ grew well on ISP media 2,3 and 4 and moderately on ISP 5 , but poor or no growth was observed on ISP media 6 and 7. Substrate mycelium was well developed, branched and light to strong yellow in colour. White aerial mycelium was produced abundantly on ISP media 3 and 4 and differentiated into straight or flexuous chains of smooth-ornamented spores. Ten or more spores were present per chain (Fig. 1). No soluble pigments were produced on any of the tested media.

Unless otherwise indicated, physiological properties were determined using ISP 2 as the basal medium. Growth was examined at $4,10,20,30,37,42$ and $45{ }^{\circ} \mathrm{C}$ and at $\mathrm{pH} 4-12$ (at intervals of $1 \mathrm{pH}$ unit). The results were recorded after 14 days of incubation at or below $30{ }^{\circ} \mathrm{C}$ and after 5 days of incubation at or above $37{ }^{\circ} \mathrm{C}$. Tolerance of $\mathrm{NaCl}$ for growth was tested on ISP 2 supplemented with 1-9\% (w/v) $\mathrm{NaCl}$ (at intervals of $1.0 \%$ ). Tolerance of $\mathrm{pH}$ and $\mathrm{NaCl}$ for growth was observed on plates incubated at $30{ }^{\circ} \mathrm{C}$ for 14 days. Decomposition of hypoxanthine, DL-tyrosine and xanthine was tested as described by Gordon et al. (1974). Oxidase activity was determined according to the method of MacFaddin (1980). Catalase and urease activities, $\mathrm{H}_{2} \mathrm{~S}$ production, nitrate reduction and hydrolysis of casein and gelatin were tested as described by Lee \& Jeong (2006). Cellulose hydrolysis was determined on ISP medium 2 supplemented with $0.5 \%$ (w/v) CM-cellulose (Sigma). Aesculin hydrolysis was tested on agar medium containing

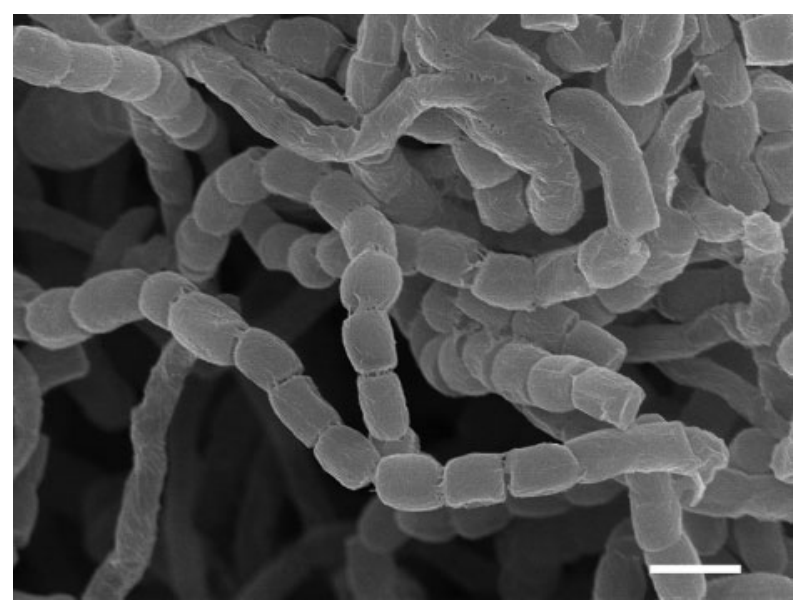

Fig. 1. Scanning electron micrograph of strain $\mathrm{CS} 5-\mathrm{AC} 15^{\top}$, showing straight to flexuous chains of smooth ornamented spores, after growth for 2 weeks at $30^{\circ} \mathrm{C}$ on ISP 4 medium. Bar, $1 \mu \mathrm{m}$.
$0.3 \%(\mathrm{w} / \mathrm{v})$ yeast extract, $0.05 \%(\mathrm{w} / \mathrm{v})$ ferric ammonium citrate, $1 \%(\mathrm{w} / \mathrm{v})$ aesculin and $0.75 \%(\mathrm{w} / \mathrm{v})$ agar, and blackening of the medium was recorded as positive after incubation for 14 days at $30{ }^{\circ} \mathrm{C}$. Hydrolysis of DNA and starch was determined using DNase test agar (Difco) and starch agar (Difco), respectively. Utilization of substrates as sole carbon and energy sources was determined using ISP 9 supplemented with carbohydrates and alcohols at final concentrations of $1 \%(\mathrm{w} / \mathrm{v})$ and organic acids at final concentrations of $0.1 \%(\mathrm{w} / \mathrm{v})$. The physiological properties of strain $\mathrm{CS} 5-\mathrm{AC} 15^{\mathrm{T}}$ are given in the species description and in Table 1.

Chromosomal DNA extraction, amplification of the $16 \mathrm{~S}$ rRNA gene by PCR and its sequencing were performed as described previously (Lee, 2006). The CLUSTAL_X program (Thompson et al., 1997) was used for multiple alignments of related sequences. Phylogenetic analyses were performed using several programs contained in the PHYLIP package (Felsenstein, 1993).

A partial 16S rRNA gene sequence (1437 nt) was determined for strain $\mathrm{CS} 5-\mathrm{AC} 15^{\mathrm{T}}$. A phylogenetic tree was reconstructed from evolutionary distances (Jukes \& Cantor, 1969) by using the neighbour-joining method (Saitou \& Nei, 1987), based on a total of $1284 \mathrm{nt}$ present in all strains between positions 95 and 1460 (Escherichia coli numbering; Brosius et al., 1978). A neighbour-joining tree (Fig. 2) indicated that strain $\mathrm{CS} 5-\mathrm{AC} 15^{\mathrm{T}}$ belonged to the family Thermomonosporaceae

Table 1. Characteristics that differentiate strain $\mathrm{CS} 5-\mathrm{AC} 15^{\top}$ from the type strain of $A$. oligospora

Strains: 1 , strain CS5-AC15 ${ }^{\mathrm{T}} ; 2$, A. oligospora JCM $10648^{\mathrm{T}}$. All data were obtained in this study, except for the cultural characteristics of A. oligospora, which were taken from Mertz \& Yao (1986).

\begin{tabular}{|lcc|}
\hline Characteristic & $\mathbf{1}$ & $\mathbf{2}$ \\
\hline Growth on ISP media 3 and 4 & Good & Poor \\
Aerial mycelium on ISP media 3 and 4 & Abundant & Trace \\
Growth at $2 \%$ (w/v) NaCl & - & + \\
Decomposition of: & & \\
Casein & - & + \\
DNA & - & + \\
Utilization of: & & \\
Adonitol & - & + \\
Cellobiose & - & + \\
Citrate & + & - \\
Dextrin & + & - \\
D-Galactose & - & + \\
Lactose & + & - \\
Melezitose & + & - \\
D-Mannitol & + & - \\
D-Ribose & - & + \\
L-Sorbose & - & + \\
Sucrose & + & - \\
\hline
\end{tabular}

${ }^{\star}$ Different response reported previously (Mertz \& Yao, 1986). 


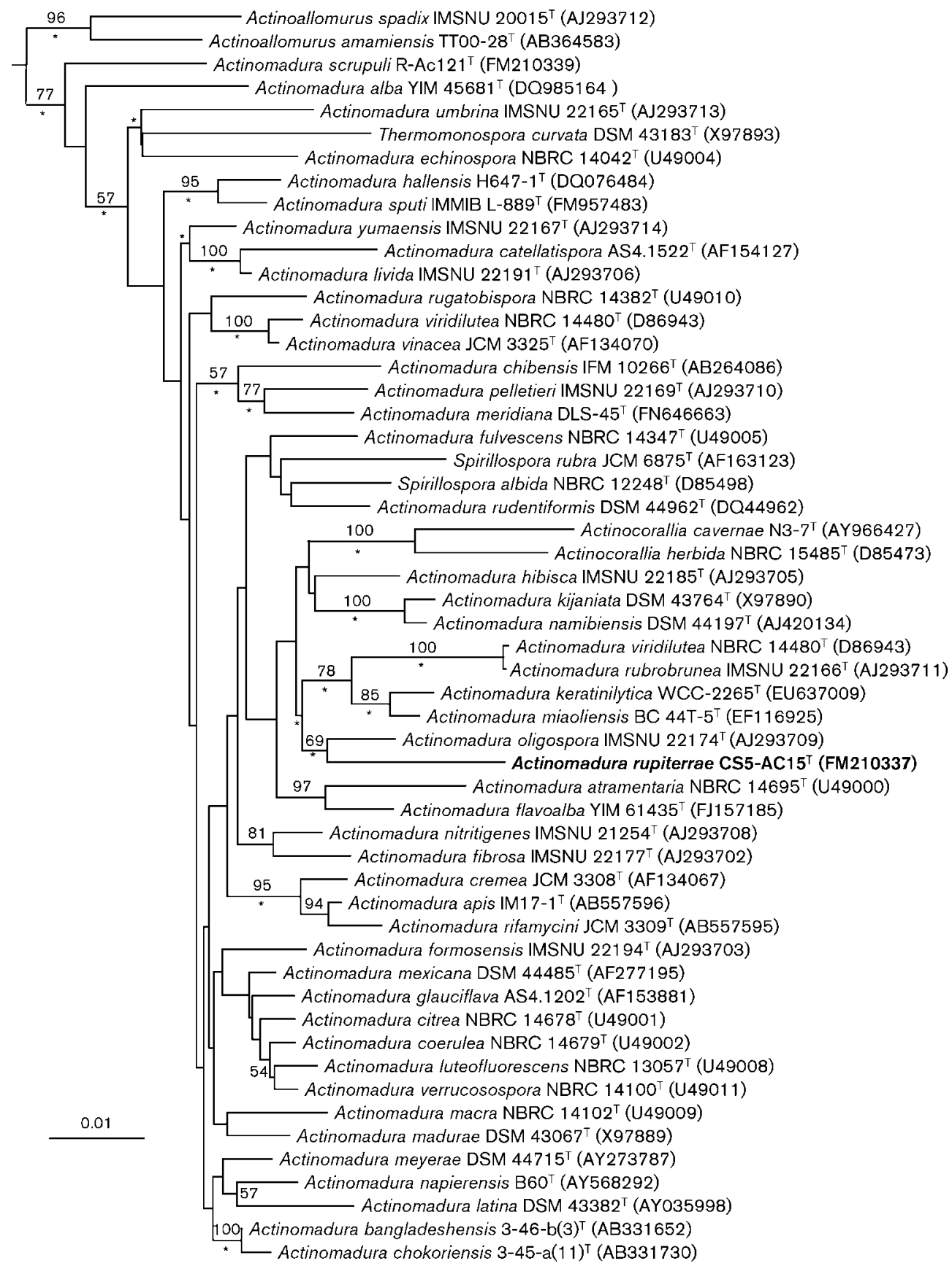

Fig. 2. Neighbour-joining (Saitou \& Nei, 1987) tree showing the phylogenetic position of strain CS5-AC15 ${ }^{\top}$ within the radiation of the family Thermomonosporaceae. Evolutionary distances were calculated using the model of Jukes \& Cantor (1969). Nocardiopsis dassonvillei DSM $43111^{\top}$ (GenBank accession no. X97886) was used as an outgroup (not shown). Asterisks indicate branches also found in the maximum-likelihood (Felsenstein, 1981) and maximum-parsimony (Fitch, 1971) trees. Bootstrap values $(>50 \%)$ are indicated at each node. Bar, 0.01 substitutions per nucleotide position.

and was closely related to A. oligospora ( $97.4 \%$ sequence similarity to the type strain). This branching pattern was supported by a moderate bootstrap value $(69 \%)$ and was also found in trees generated by the maximum-parsimony and maximum-likelihood algorithms. Strain CS5-AC15 showed 16S rRNA gene sequence similarity values lower than $96.8 \%$ to other species of the genus Actinomadura and related taxa.

The following chemotaxonomic characteristics were analysed, with biomass obtained from cultures grown in ISP 2 broth for 7 days at $30{ }^{\circ} \mathrm{C}$ : the isomer of diaminopimelic 
acid (Staneck \& Roberts, 1974), whole-cell sugars (Becker et al., 1965), menaquinones (Kroppenstedt, 1985), $N$-acyl type of murein in the cell wall (Uchida \& Aida, 1984), polar lipids (Minnikin et al., 1977) and mycolic acids (Minnikin et al., 1980). For fatty acid analysis, strain CS5-AC15 ${ }^{\mathrm{T}}$ and A. oligospora JCM $10648^{\mathrm{T}}$ were grown on ISP 2 for 6 days at $30{ }^{\circ} \mathrm{C}$. Methyl esters of cellular fatty acids were prepared and analysed by gas chromatography according to the instructions of the Sherlock Microbial Identification System (version 2.11; MIDI), using the AEROBE package including the TSBA (version 3.9), CLIN (version 3.9) and MI7H10 (version 3.8) databases for identification of fatty acids.

The cell wall of strain $\mathrm{CS} 5-\mathrm{AC} 15^{\mathrm{T}}$ contained mesodiaminopimelic acid as the diagnostic diamino acid and madurose and glucose as whole-cell sugars, showing that it possessed cell-wall type III (Lechevalier \& Lechevalier, 1970a) and whole-cell sugar pattern B (Lechevalier, 1968). The acyl type of murein in the peptidoglycan was acetyl. The menaquinones of strain CS5-AC15 ${ }^{\mathrm{T}}$ were MK- $9\left(\mathrm{H}_{6}\right)(62 \%)$, MK-9 $\left(\mathrm{H}_{8}\right)(31 \%)$ and MK-9 $\left(\mathrm{H}_{4}\right)(7 \%)$. A. oligospora JCM $10648^{\mathrm{T}}$ contained a similar menaquinone profile, at a peak ratio of $71: 27: 2$ in this study. The polar lipids were diphosphatidylglycerol, phosphatidylglycerol, phosphatidylinositol and unknown phospholipids, showing a phospholipid type PI pattern (Lechevalier et al., 1981). Mycolic acids were not detected. The fatty acid profile of strain CS5-AC15 ${ }^{\mathrm{T}}$ contained saturated, unsaturated iso-branched and 10methyl-branched fatty acids. The predominant fatty acids (>10\% of the total) were $\mathrm{C}_{16: 0}(31.1 \%), \mathrm{C}_{18: 1} \omega 9 \mathrm{c}(21.5 \%)$ and iso- $\mathrm{C}_{16: 0}(11.1 \%)$. A. oligospora JCM $10648^{\mathrm{T}}$ showed a similar profile, but differed from strain $\mathrm{CS} 5-\mathrm{AC}^{2} 5^{\mathrm{T}}$ in the relative proportions of 10-methyl $\mathrm{C}_{18: 0}$ (TBSA) and iso$\mathrm{C}_{16: 0}$ (see Table S1, available in IJSEM Online). The G $+\mathrm{C}$ content of the DNA was $70.9 \mathrm{~mol} \%$, as determined by HPLC (Mesbah et al., 1989).

A phylogenetic tree (Fig. 2) showed that strain CS5-AC15 ${ }^{\mathrm{T}}$ belongs to the family Thermomonosporaceae and is closely related to A. oligospora. The combination of morphological and chemotaxonomic data supports the assignment of the strain to the genus Actinomadura. Phenotypic features that differentiate strain $\mathrm{CS} 5-\mathrm{AC} 5^{\mathrm{T}}$ from $A$. oligospora $\mathrm{JCM}$ $10648^{\mathrm{T}}$ are shown in Tables 1 and S1. Strain CS5-AC15 showed good growth and produced abundant aerial mycelium on ISP media 3 and 4 , in contrast to $A$. oligospora (Mertz \& Yao, 1986). Strain CS5-AC15 ${ }^{\mathrm{T}}$ can be further differentiated from A. oligospora by utilization of carbohydrates and hydrolysis of casein and DNA (Table 1).

DNA-DNA hybridization experiments were performed according to the photobiotin-labelling method of Ezaki et al. (1989). Genomic DNA was extracted and purified by the method of Hopwood et al. (1985). Five replications were carried out for each DNA pairing and the highest and lowest scores for each DNA pairing were excluded. Finally, DNA relatedness values were recorded as mean \pm SD values for the remaining three scores (Yoon et al., 2007). DNA-DNA relatedness between strain CS5-AC15 ${ }^{\mathrm{T}}$ and A. oligospora JCM $10648^{\mathrm{T}}$ was $37.9 \pm 0.7 \%$, well below the $70 \%$ cut-off value recommended for the delineation of bacterial genospecies (Wayne et al., 1987).

Based on the phenotypic, phylogenetic and DNA-DNA hybridization data presented here, strain $\mathrm{CS} 5-\mathrm{AC} 5^{\mathrm{T}}$ is considered to represent a novel species of the genus Actinomadura, for which the name Actinomadura rupiterrae sp. nov. is proposed.

\section{Description of Actinomadura rupiterrae sp. nov.}

Actinomadura rupiterrae (ru.pi.ter'rae. L. fem. n. rupes cliff; L. fem. n. terra soil; N.L. gen. n. rupiterrae of cliff soil, referring to the sample from which the type strain was isolated).

Catalase-positive. Oxidase-negative. Grows well on ISP 2, 3 and 4 media. Substrate mycelium is well-developed, branched and light to strong yellow in colour. Aerial mycelium is produced abundantly on ISP 3 and 4 and differentiates into straight to flexuous chains of ten or more spores. The spore surface is smooth. Growth occurs at 20$42{ }^{\circ} \mathrm{C}$ (optimum, $37-42{ }^{\circ} \mathrm{C}$ ), at $\mathrm{pH}$ 5-11 (optimum, pH 68 ) and in the presence of up to $1 \%(\mathrm{w} / \mathrm{v}) \mathrm{NaCl}$. Aesculin and gelatin are hydrolysed, but casein, DNA, CM-cellulose, starch and urea are not. Hypoxanthine, DL-tyrosine and xanthine are not decomposed. $\mathrm{H}_{2} \mathrm{~S}$ production and nitrate reduction are not observed. Citrate, dextran, D-glucose, lactose, D-mannitol, melezitose and sucrose are utilized as sole carbon sources. Acetate, adonitol, D- and L-arabinose, benzoate, 2,3-butanediol, cellobiose, dulcitol, meso-erythritol, formate, D-fructose, D-galactose, glycerol, myo-inositol, inulin, DL-malate, maltose, methyl $\alpha$-D-glucoside, methyl $\alpha$ D-mannoside, 1,2-propanediol, raffinose, L-rhamnose, Dribose, salicin, D-sorbitol, L-sorbose, succinate, trehalose, DL-tartrate, D-xylitol and D-xylose are not utilized. mesoDiaminopimelic acid is the diagnostic diamino acid and madurose is the characteristic sugar (type III/B cell wall). The acyl type of muramic acid is acetyl. The major menaquinones are MK-9 $\left(\mathrm{H}_{6}\right)$ and MK- $9\left(\mathrm{H}_{8}\right)$. The polar lipids are diphosphatidylglycerol, phosphatidylglycerol, phosphatidylinositol and unknown phospholipids. Mycolic acids are absent. The predominant fatty acids are $\mathrm{C}_{16: 0}$, $\mathrm{C}_{18: 1} \omega 9 c$ and iso- $\mathrm{C}_{16: 0}$.

The type strain, CS5-AC15 $5^{\mathrm{T}}\left(=\mathrm{KCTC} 19559^{\mathrm{T}}=\mathrm{DSM}\right.$ $\left.45251^{\mathrm{T}}\right)$, was isolated from a soil sample collected from a cliff on Mara Island, Jeju, Republic of Korea. The G+C content of the DNA of the type strain is $70.9 \mathrm{~mol} \%$.

\section{Acknowledgements}

This work was supported by the 21C Frontier Program of Microbial Genomics and Applications (grant 11-2008-01-003-00) from the Ministry of Education, Science \& Technology (MEST) of the Republic of Korea. The author is grateful to Dr T. Kudo for providing the type strain of $A$. oligospora. 


\section{References}

Becker, B., Lechevalier, M. P. \& Lechevalier, H. A. (1965). Chemical composition of cell-wall preparation from strains of various form-genera of aerobic actinomycetes. Appl Microbiol 13, 236-243.

Brosius, J., Palmer, M. L., Kennedy, P. J. \& Noller, H. F. (1978). Complete nucleotide sequence of a $16 \mathrm{~S}$ ribosomal RNA gene from Escherichia coli. Proc Natl Acad Sci U S A 75, 48014805.

Ezaki, T., Hashimoto, Y. \& Yabuuchi, E. (1989). Fluorometric deoxyribonucleic acid-deoxyribonucleic acid hybridization in microdilution wells as an alternative to membrane filter hybridization in which radioisotopes are used to determine genetic relatedness among bacterial strains. Int J Syst Bacteriol 39, 224-229.

Felsenstein, J. (1981). Evolutionary trees from DNA sequences: a maximum likelihood approach. J Mol Evol 17, 368-376.

Felsenstein, J. (1993). PHYLIP (phylogeny inference package), version 3.51c. Distributed by the author. Department of Genome Sciences, University of Washington, Seattle, USA.

Fitch, W. M. (1971). Towards defining the course of evolution: minimum change for a specific tree topology. Syst Zool 20, 406-416.

Gordon, R. E., Barnett, D. A., Handerhan, J. E. \& Pang, C. H.-N (1974). Nocardia coeliaca, Nocardia autotrophica, and the nocardin strain. Int J Syst Bacteriol 24, 54-63.

Hopwood, D. A., Bibb, M. J., Chater, K. F., Kieser, T., Bruton, C. J., Kieser, H. M., Lydiate, D. J., Smith, C. P., Ward, J. M. \& Schrempf, H. (editors) (1985). Genetic Manipulation of Streptomyces. A Laboratory Manual. Norwich: John Innes Foundation.

Jukes, T. H. \& Cantor, C. R. (1969). Evolution of protein molecules. In Mammalian Protein Metabolism, vol. 3, pp. 21-132. Edited by H. N. Munro. New York: Academic Press.

Kroppenstedt, R. M. (1985). Fatty acid and menaquinone analysis of actinomycetes and related organisms. In Chemical Methods in Bacterial Systematics (Society for Applied Bacteriology Technical Series vol. 20), pp. 173-199. Edited by M. Goodfellow \& D. E. Minnikin. New York: Academic Press.

Kroppenstedt, R. M. \& Goodfellow, M. (1991). The family Thermomonosporaceae. In The Prokaryotes, 2nd edn, pp. 1085-1114. Edited by A. Balows, H. G. Trüper, M. Dworkin, W. Harder \& K. H. Schleifer. New York: Springer.

Kroppenstedt, R. M. \& Goodfellow, M. (2006). The family Thermomonosporaceae: Actinocorallia, Actinomadura, Spirillospora and Thermomonospora. In The Prokaryotes, 3rd edn, pp. 682-724. Edited by M. Dworkin, S. Falkow, E. Rosenberg, K. H. Schleifer \& E. Stackebrandt. New York: Springer.

Küster, E. \& Williams, S. T. (1964). Selection of media for isolation of streptomycetes. Nature 202, 928-929.

Lechevalier, M. P. (1968). Identification of aerobic actinomycetes of clinical importance. J Lab Clin Med 71, 934-944.

Lechevalier, M. P. \& Lechevalier, H. A. (1970a). Composition of whole cell hydrolysates as a criterion in the classification of aerobic actinomycetes. In The Actinomycetales, pp. 311-316. Edited by H. Prauser. Jena: Gustav Fischer.

Lechevalier, H. A. \& Lechevalier, M. P. (1970b). A critical evaluation of the genera of aerobic actinomycetes. In The Actinomycetales, pp. 393-405. Edited by H. Prauser. Jena: Gustav Fischer.

Lechevalier, M. P., Stern, A. E. \& Lechevalier, H. A. (1981) Phospholipids in the taxonomy of actinomycetes. Zentralbl Bakteriol Hyg Abt 1 (Suppl. 11), 111-116.
Lee, S. D. (2006). Kineococcus marinus sp. nov., isolated from marine sediment of the coast of Jeju, Korea. Int J Syst Evol Microbiol 56, 1279-1283.

Lee, S. D. (2012). Actinomadura meridiana sp. nov., isolated from mountain soil. Int J Syst Evol Microbiol 62, 217-222.

Lee, S. D. \& Jeong, H. S. (2006). Actinomadura hallensis sp. nov., a novel actinomycete isolated from Mt. Halla in Korea. Int J Syst Evol Microbiol 56, 259-264.

Lee, D. W. \& Lee, S. D. (2010). Actinomadura scrupuli sp. nov., isolated from rock. Int J Syst Evol Microbiol 60, 2647-2651.

MacFaddin, J. F. (1980). Biochemical Tests for Identification of Medical Bacteria, 2nd edn. Baltimore: Williams \& Wilkins.

Mertz, F. P. \& Yao, R. C. (1986). Actinomadura oligospora sp. nov., the producer of a new polyether antibiotic. Int J Syst Bacteriol 36, 179182.

Mesbah, M., Premachandran, U. \& Whitman, W. B. (1989). Precise measurement of the $\mathrm{G}+\mathrm{C}$ content of deoxyribonucleic acid by highperformance liquid chromatography. Int J Syst Bacteriol 39, 159-167.

Meyer, J. (1989). Genus Actinomadura. In Bergey's Manual of Systematic Bacteriology, vol. 4, pp. 2511-2526. Edited by S. T. Williams, M. E. Sharpe \& J. G. Holt. Baltimore: Williams \& Wilkins.

Minnikin, D. E., Patel, P. V., Alshamaony, L. \& Goodfellow, M. (1977). Polar lipid composition in the classification of Nocardia and related bacteria. Int J Syst Bacteriol 27, 104-117.

Minnikin, D. E., Hutchinson, I. G., Caldicott, A. B. \& Goodfellow, M. (1980). Thin layer chromatography of methanolysates of mycolic acid-containing bacteria. J Chromatogr A 188, 221-233.

Promnuan, Y., Kudo, T., Ohkuma, M. \& Chantawannakul, P. (2011). Actinomadura apis sp. nov., isolated from a honey bee (Apis mellifera) hive, and the reclassification of Actinomadura cremea subsp. rifamycini Gauze et al. 1987 as Actinomadura rifamycini (Gauze et al. 1987) sp. nov., comb. nov. Int J Syst Evol Microbiol 61, 2271-2277.

Puhl, A. A., Selinger, L. B., McAllister, T. A. \& Inglis, G. D. (2009). Actinomadura keratinilytica sp. nov., a keratin-degrading actinobacterium isolated from bovine manure compost. Int J Syst Evol Microbiol 59, 828-834.

Qin, S., Zhao, G.-Z., Li, J., Zhu, W.-Y., Xu, L.-H. \& Li, W.-J. (2009). Actinomadura flavalba sp. nov., an endophytic actinomycete isolated from leaves of Maytenus austroyunnanensis. Int J Syst Evol Microbiol 59, 2453-2457.

Saitou, N. \& Nei, M. (1987). The neighbor-joining method: a new method for reconstructing phylogenetic trees. Mol Biol Evol 4, 406425.

Shirling, E. B. \& Gottlieb, D. (1966). Methods for characterization of Streptomyces species. Int J Syst Bacteriol 16, 313-340.

Staneck, J. L. \& Roberts, G. D. (1974). Simplified approach to identification of aerobic actinomycetes by thin-layer chromatography. Appl Microbiol 28, 226-231.

Thompson, J. D., Gibson, T. J., Plewniak, F., Jeanmougin, F. \& Higgins, D. G. (1997). The CLUSTAL_X windows interface: flexible strategies for multiple sequence alignment aided by quality analysis tools. Nucleic Acids Res 25, 4876-4882.

Tseng, M., Yang, S.-F., Hoang, K.-C., Liao, H. C., Yuan, G. F. \& Liao, C. C. (2009). Actinomadura miaoliensis sp. nov., a thermotolerant polyester-degrading actinomycete. Int J Syst Evol Microbiol 59, 517520 .

Uchida, K. \& Aida, K. (1984). An improved method for the glycolate test for simple identification of the acyl type of bacterial cell walls. J Gen Appl Microbiol 30, 131-134. 
Wayne, L. G., Brenner, D. J., Colwell, R. R., Grimont, P. A. D., Kandler, O., Krichevsky, M. I., Moore, L. H., Moore, W. E. C., Murray,

R. G. E. \& other authors (1987). International Committee on Systematic Bacteriology. Report of the ad hoc committee on reconciliation of approaches to bacterial systematics. Int $J$ Syst Bacteriol 37, 463-464.
Yassin, A. F., Spröer, C., Siering, C. \& Klenk, H. P. (2010). Actinomadura sputi sp. nov., isolated from the sputum of a patient with pulmonary infection. Int J Syst Evol Microbiol 60, 149-153.

Yoon, J.-H., Kang, S.-J., Lee, S.-Y. \& Oh, T.-K. (2007). Loktanella maricola sp. nov., isolated from seawater of the East Sea in Korea. Int J Syst Evol Microbiol 57, 1799-1802. 